Archive for

Organic Chemistry

Arkivoc 2019, part vi, 0-0

\title{
Efficient monoacylation of symmetrical secondary alkanediamines and synthesis of unsymmetrical diacylated alkanediamines. A new L-proline-based organocatalyst
}

\author{
Laure Moulat, Jean Martinez, and Xavier J. Salom-Roig* \\ Institut des Biomolécules Max Mousseron (IBMM), UMR 5247, Université de Montpellier, CNRS, ENSCM, \\ Place Eugène Bataillon, 34095 Montpellier, France \\ Email: Xavier.Salom-Roig@umontpellier.fr
}

Received 09-03-2019

Accepted 11-13-2019

Published on line $01-12-2020$

\section{Abstract}

A simple procedure was developed for the monoacylation of several unprotected alkanediamines with carboxylic acids by using PyBOP-HOBt as coupling agent in the presence of DIEA at room temperature. Yields were moderate with primary alkanediamines and good to excellent with linear or cyclic secondary ones. To illustrate the utility of these monoacylated products, six unsymmetrical diacylated alkanediamines were synthesized. In addition, one of these compounds was evaluated as organocatalyst in an asymmetric aldol reaction.
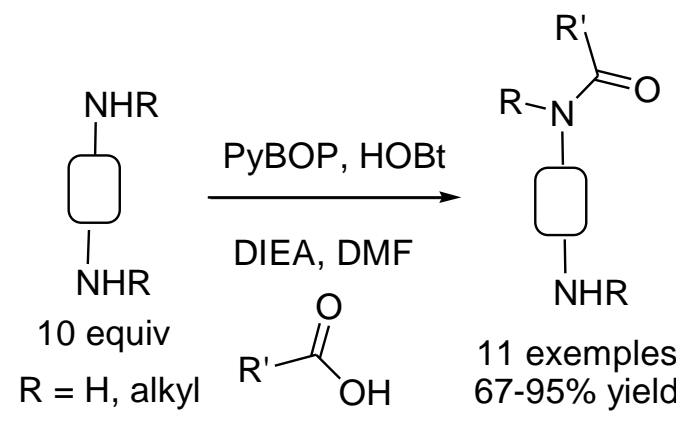

11 exemples $67-95 \%$ yield
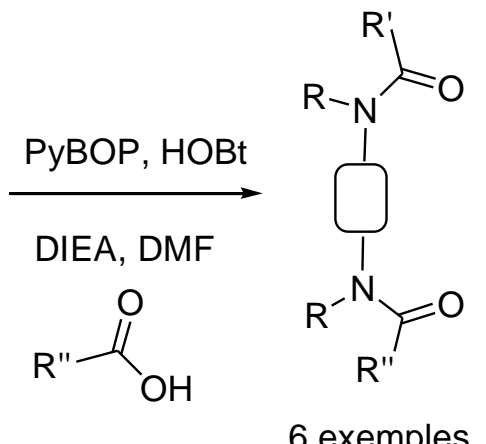

Keywords: Monoacylated alkanediamines, unsymmetrical diacylated alkanediamines, pseudopeptidic derivatives, organocatalyst 


\section{Introduction}

Unsymmetrical diacylated alkanediamines (A, Fig. 1) are a widely occurring structural component incorporated into numerous interesting molecules usually evaluated for biological purposes. Examples can be found in the field of fluorescent molecular probes ${ }^{1-9}$ and bioactive compounds. ${ }^{10-17}$ As shown in Figure 1 , the synthetic strategy leading to unsymmetrical diacylated alkanediamines involves a mono acylated alkanediamine (B) as precursor. For the synthesis of $\mathbf{B}$, in order to avoid the formation of the parasite diacylated product, the common strategy normally used by investigators is the sequence consisting in the acylation of a premonoprotected alkanediamine (C) followed by the protecting group cleavage. A myriad of examples using this tedious and time-consuming strategy exists in the literature. ${ }^{1-18}$

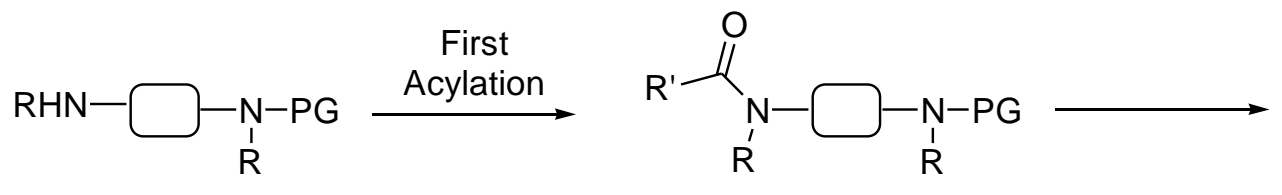

C; PG = Protecting group
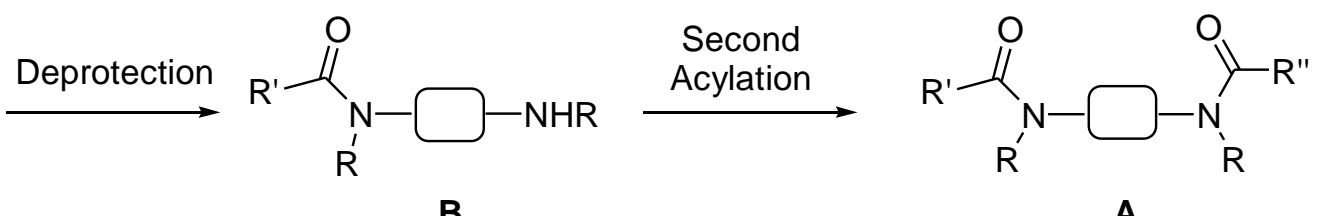

A

Figure 1. Strategy for the classical synthesis of unsymetrical diacylated alkanediamines A.

In this paper we describe a shorter strategy leading to monoacylated (B) and diacylated alkanediamines (A), which doesn't require the use of a pre-monoprotected alkanediamine (C). This strategy is particularly efficient for secondary alkanediamines.

Monoacylated symmetrical alkanediamines (B) are valuable scaffolds that appear in the chemical structure of several biologically active compounds in medicinal chemistry. Figure 2 provides representative examples including the cardiotonic agent vesnarinone ${ }^{19}(\mathbf{1})$ and the antihypertensive agents doxazosin (2), prazosin (3) and terazosin (4)..$^{20}$

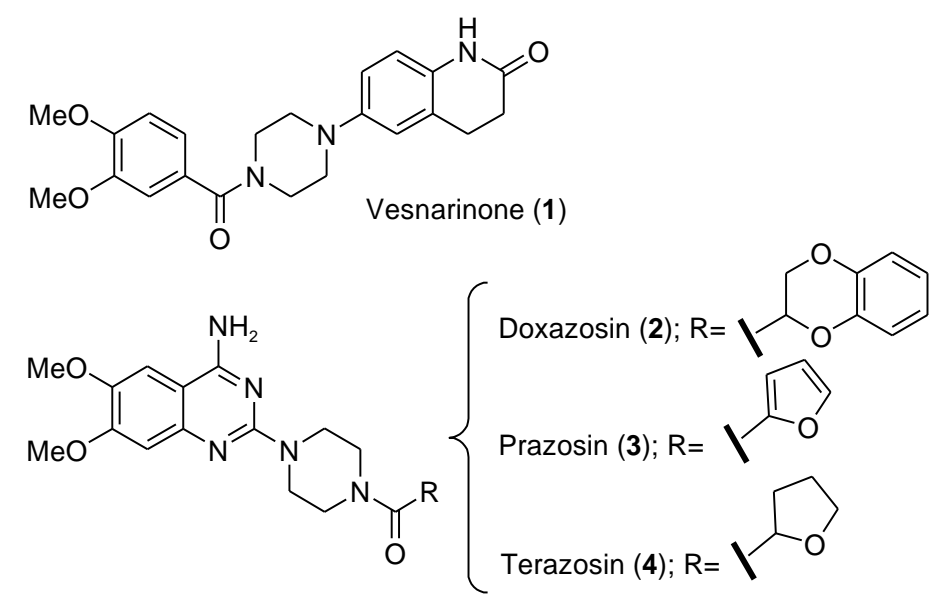

Figure 2. Bioactive compounds bearing a monoacylated moiety. 
However, monoacylation of symmetrical diamines remains difficult. ${ }^{21}$ Thus, treating a symmetrical alkanediamine with one equivalent of an acylating agent is expected to yield a statistical distribution of products comprising unreacted starting alkanediamine and the mono- and diacylated products (Fig. 3). Consequently, the maximum theoretical yield of the monoacylated product reach $50 \%$ with the yield of the diacylated material not exceeding 25\%. Unfortunately, the diacylated products are often formed predominantly or exclusively, even though the alkanediamine is present in large excess over the acylating agent. Such finding was attributed by Sayre and co-workers ${ }^{22}$ to a mixing problem due to the rapidity of the acylation reaction. Thus, the initial monoacylated product formed at the interface between the drop of the acylated agent and the alkanediamine solutions is acylated a second time at this interface before being dispersed in the reaction medium.

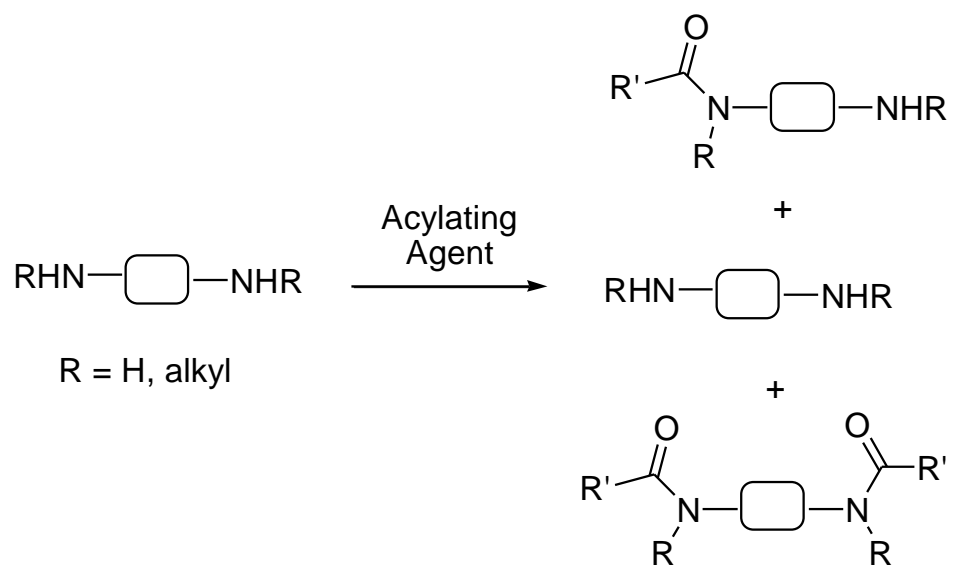

Figure 3. Acylation of unprotected alkanediamines.

In light of this, monoacylation of symmetrical diamines has attracted considerable interest from the synthetic community and several methodologies have already been published. Thus, in the case of alkanediamines with short hydrocarbon chains one can minimize diacylation at a controlled $\mathrm{pH}^{23-24} \mathrm{By}$ increasing reactant dilution and decreasing reactivity of the acylating agent, Sayre reached a statistical yield for the mono-acylation of 1,2-ethanediamine and 1,4-butanediamine. ${ }^{22}$ Furthermore, Chou's group obtained monoacylated products in excellent yields by one-pot neat reaction of aliphatic or aromatic carboxylic esters and alkanediamines. ${ }^{25}$ Wang's strategy focused on the reaction of one equivalent of an acylating agent with the previously prepared alkanediamine Li di-anion. ${ }^{26}$ The same group also reached monoacylation by using 9BBN to protect one of the two amino groups. ${ }^{27}$ By using ionic immobilization of piperazine and homopiperazine to sulfonic acid-functionalized silica gel, monoacylation was also realized. ${ }^{28}$ Lai reported a convenient method for preparing aryl monoacylated piperazine derivatives by using trimethylacetic arylcarboxylic anhydrides. ${ }^{29}$ Fang developed a protocol leading to monoacylated alkanediamines by reacting phenyl esters with a phenyl carbonate as acylation agents in the presence of water. ${ }^{30}$ Finally, most recently, Bandgar obtained a series of monoacylated piperazine derivatives by the reaction of carboxylic acids with 2chloro-4,6-dimethoxy-1,3,5-triazine. ${ }^{31}$ Most of the synthetic methods described above suffer from drawbacks, notably the use of drastic reaction conditions or aggressive reagents or are limited to aryl acylations. Therefore, there still exists a need to develop simply and general procedures more efficient than those currently in existence. 


\section{Results and Discussion}

In this context, our interest in acylated alkanediamines arose from a desire to access a convenient monoacylation procedure for the preparation of secondary and tertiary amides by reaction of carboxylic acids with linear or cyclic alkylenediamines. Thus, we accomplished the synthesis of monoacylated derivatives starting from commercially available carboxylic acids, which were coupled to the corresponding inexpensive alkanediamine in excess utilizing PyBOP-HOBt ${ }^{32-34}$ as coupling agent in the presence of DIEA and DMF as a solvent. The desired monoacylated alkanediamines could be obtained after purification by column chromatography on silica gel in moderated yields for primary amines to excellent yields for secondary ones.

As shown in Table 1, we first examined the monoacylation of two primary alkanediamines (1,2ethanediamine and 1,6-hexanediamine) using $N$-Boc-protected lysine (5, entries 1 and 2), N-Boc-protected phenylalanine (6, entries 3 and 4 ) and (S)-naproxen (7, entries 5 and 6 ) as acylating agents. As expected, the corresponding monoacylated alkanediamines were obtained in low to moderate yields due to the concomitant presence of the corresponding diacylated analogues in a range of $20-30 \%$. Thus, while 1,2-ethanediamine led to 8, 10 and 12 in disappointing yields (30-31\%), 1,6-hexanediamine furnished the corresponding monoacylated products $\mathbf{9}, \mathbf{1 1}$ and 13 in yields ranging from 51 to $56 \%$.

Table 1. Monoacylated primary alkanediamines prepared by PyBOP/HOBt coupling

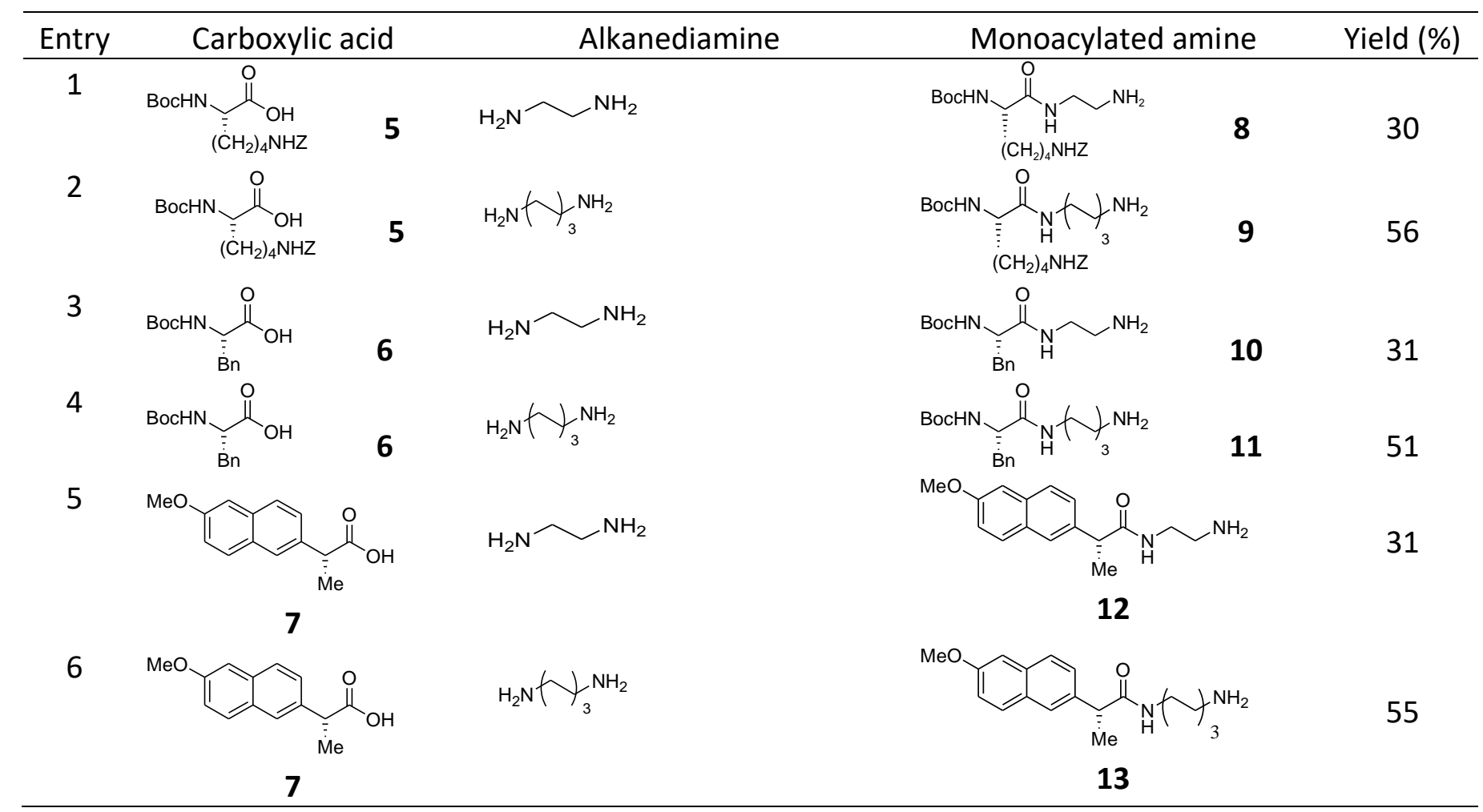

Interestingly, as we carried out the monoacylation of cyclic alkanediamines (piperazine and homopiperazine, Table 2) using the same conditions described before (vide supra), the reaction crudes were proved by LC-MS to contain only traces of the contaminant diacylated alkane diamines. The use of an excess of alkane diamine was necessary to avoid the formation of significant amounts of the corresponding diacylated alkanediamines. Consequently, the corresponding monoacylated piperazine and homopiperazine derivatives were obtained, after purification by column chromatography on silica gel, in good to high yields (67-96\%). As shown in Table 2, monoacylated homopiperazine compounds were obtained in somewhat lower yields than 
piperazine analogues (compare entries 1,3 and 5 with entries 2,4 and 6. (S)-Naproxen was reacted with a linear secondary amine (entry 7) yielding the corresponding tertiary amide $\mathbf{2 5}$ in $\mathbf{9 6 \%}$ yield and confirming that the nucleophilic power of cyclic diamines and not their constrained form was responsible for their better reactivity compared to primary amines. In order to demonstrate the general scope of this procedure, we also prepared in good yields $N$-acylpiperazines 26-28 (entries 8-10) as precursors of vesnarinone (1) and the antihypertensive agents doxazosin (2) and a prazosin 2-thienyl analogue respectively in addition to compound 29 bearing a linear chain. ${ }^{35}$

Table 2. Monoacylated secondary alkanediamines prepared by PyBOP/HOBt coupling

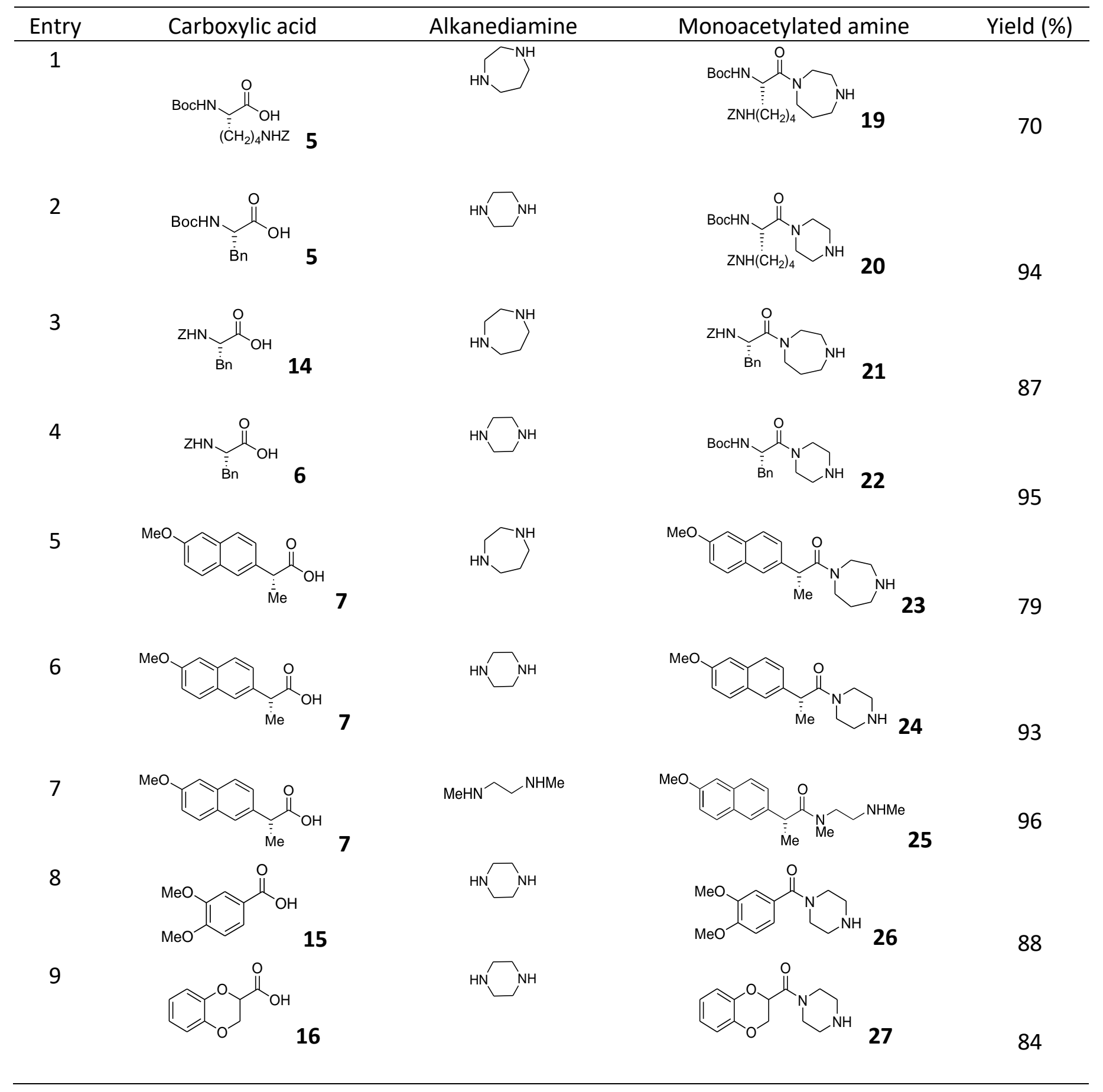


Table 2. Continued

\begin{tabular}{|c|c|c|c|c|}
\hline Entry & Carboxylic acid & Alkanediamine & Monoacetylated amine & Yield (\%) \\
\hline \multirow[t]{2}{*}{10} & & & & \\
\hline & 17 & & 28 & 67 \\
\hline 11 & 18 & & 29 & 98 \\
\hline
\end{tabular}

The synthetic potential of this methodology was further exemplified by using the monoacylated alkanediamines in hand as intermediates for the construction of unsymmetrical diacylated alkanediamines. Thus, in a first time, we synthesized a series of six pseudopeptidic derivatives which were studied as supramolecular receptors for non-steroidal antiinflammatory drugs. ${ }^{36-37}$ For this meaning, as detailed in Scheme 1, in compounds $\mathbf{8}, \mathbf{9}$ and $\mathbf{1 0}$, the remaining free amine was coupled to commercially available Boctryp-OH by using the PyBOP/HOBt methodology $32-34$ in the presence DIEA obtaining the pseudopeptidic models 30, 31 and $\mathbf{3 3}$ in good yields. Analogously, we carried out the coupling of compounds 10 and 22 with Boc-tyr-OH providing models $\mathbf{3 2}$ and $\mathbf{3 4}$. Finally, the $\mathrm{N}$-monoacylated compound $\mathbf{1 0}$ was reacted with Z-Pro$\mathrm{OH}$ giving, after cleavage of the proline amine protecting group, the unsymmetrical diacylated piperazine 35 .

During the last years, L-proline-based compounds have been successfully employed in asymmetric organocatalysis enlarging the scope of the natural amino acid. ${ }^{38-41}$ In this context, we decided to evaluate the catalytic properties of the proline-based compound 35.

As a benchmark reaction, we examined the aldol reaction between $p$-nitrobenzaldehyde and acetone. The results of this study are reported in Table 3.

In our initial experiments, we screened various solvent systems by using $30 \mathrm{~mol} \%$ catalyst $\mathbf{3 5}$ to promote the reaction (entries 1-4). Thus, in a 1:4 acetone/DMSO mixture, ${ }^{42}$ after stirring the homogenous reaction mixture for 8 days at room temperature, chiral-phase HPLC analysis revealed that the expected aldol product 36 was formed in 19\% ee. When using DMF instead of DMSO as a co-solvent, the reaction took place in 5 days improving slightly the enantioselectivity. With the system acetone/AcCN (1:4), after 3 days, the ee was enhanced to $36 \%$ with a $92 \%$ of conversion rate. The use of chloroform as a co-solvent induced lower enantioselectivity and gave a shorter reaction time. We decided then to conduct the reaction with acetone serving as an only solvent. Thus, aldol $\mathbf{3 6}$ was formed in $46 \%$ ee (entry 5). By decreasing the catalyst loading to $10 \%$, the reaction rate increased and the ee dropped dramatically (entry 6). By further reduction of the amount of the catalyst (5\%) only $54 \%$ of conversion was achieved after 3 days with a comparable enantiomeric excess (entry 7 ). The increase of the quantity of catalyst (50\%) considerably accelerated the reaction (4h) but resulted in a lower enantioselectivity (entry 8). Finally, we studied the influence of the reaction temperature in the enantioselectivity (entries 9-11). Thus, when the reaction was carried out at $0^{\circ} \mathrm{C}$, the ee increased to $52 \%$. The best result was obtained when the reaction proceeded at $-20^{\circ} \mathrm{C}$ giving the hydroxyketone 36 in $69 \%$ yield and $72 \%$ ee. Further decrease of the reaction temperature to $-30^{\circ} \mathrm{C}$ reduced somewhat the ee value $(66 \%)$. 


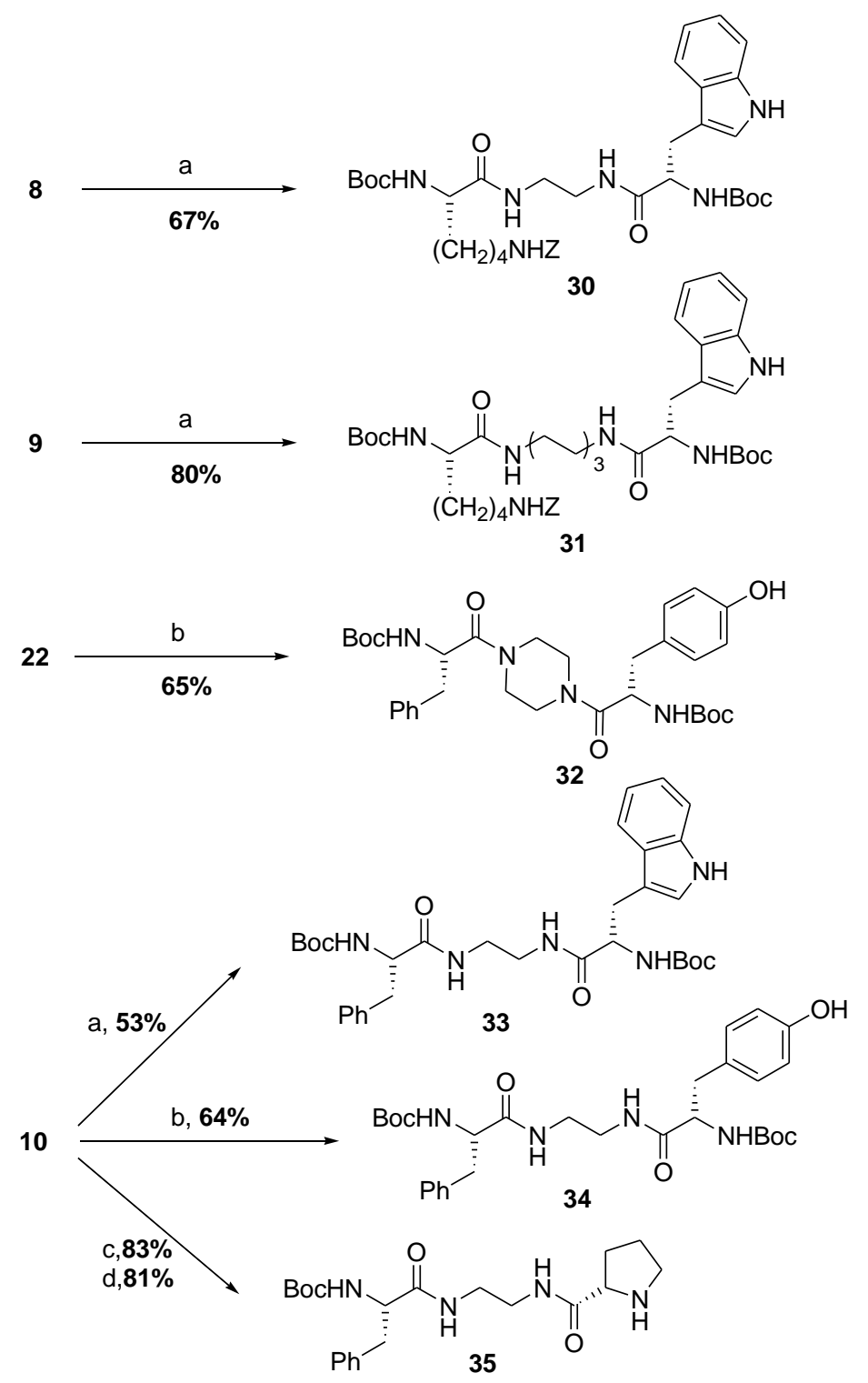

Scheme 1. Synthesis of unsymmetrical diacylated alkanediamines. Reagents and conditions: a: Boc-Trp-OH, PyBOP (1 equiv), HOBt (2 equiv), DIEA (2 equiv) in anhydrous DMF, 24 h; b: Boc-Tyr-OH, PyBOP (1 equiv), HOBt (2 equiv), DIEA (2 equiv) in anhydrous DMF, 24 h; c: Z-Pro-OH, PyBOP (1 equiv), HOBt (2 equiv), DIEA (2 equiv) in anhydrous DMF, $24 \mathrm{~h}$; d: $\mathrm{H}_{2}, \mathrm{Pd}(\mathrm{OH})_{2} / \mathrm{C}, \mathrm{EtOH}$.

Interestingly, when the reaction was conducted by using L-proline as a catalyst with acetone serving as a solvent, no reaction occurred after 3 days stirring of the heterogeneous mixture (entry 12). We attributed this lack of reactivity to the low solubility of proline in acetone. In order to get the completion of the reaction promoted by proline, a 1:4 acetone/DMSO solvent system is necessary (entries 13 and 14). ${ }^{42,43}$ Compared to the described conditions using proline as catalyst at room temperature or at $-20^{\circ} \mathrm{C}$ (entries 13 and 14 ), we observed similar yield and enantioselectivity by using our proline-based organocatalyst 35 at $-20^{\circ} \mathrm{C}$. However, it is worth mentioning that in our case the use of DMSO, which is not easy to remove, as a co-solvent was not necessary. 
Table 3. Aldol Reaction between $p$-Nitrobenzaldehyde and Acetone Catalyzed by proline derivative 35

\begin{tabular}{cccccccc} 
& & & & & & \\
\hline
\end{tabular}

${ }^{a}$ Conversion and enantioselectivity of the aldol product were determined by analytical chiral HPLC analysis on a chiralpak AS-H column, detection at $270 \mathrm{~nm}$. b $\mathrm{No}$ secondary products were observed by analytical chiral HPLC analysis. 'The absolute configuration of the major enantiomer was assigned by comparison with literature data. ${ }^{\mathrm{d} C o m p o u n d} \mathbf{3 6}$ was isolated with $69 \%$ yield.

\section{Conclusions}

In conclusion, a convenient protocol to obtain monoacylated acyclic and cyclic alkanediamines has been developed. We have demonstrated that this is a general procedure leading to secondary, and more efficiently to tertiary amides, and illustrated its utility by preparing in good yields three monoacylated piperazine derivatives as key intermediates in the synthesis of bioactive compounds. This simple procedure provides a practical and timely method for the synthesis of unsymmetrical diacylated alkanediamines, avoiding the employment of any pre-protected alkanediamine as we have demonstrated by the synthesis of six pseudopeptidic derivatives. This protocol is particularly useful for the acylation of inexpensive alkanediamines with precious carboxylic acids. We strongly believe that this methodology will find broad application in synthetic organic chemistry. In addition, one of these compounds was tested as organocatalyst in an asymmetric aldol reaction showing similar results to that described in the literature employing proline. Further studies focusing on new applications of this promising proline-based catalyst and analogues are now under investigation. 


\section{Experimental Section}

General. All reagents and solvents were purchased from commercial sources. Reactions were conducted in flame-dried glassware under an argon atmosphere. ${ }^{1} \mathrm{H}$ NMR and ${ }^{13} \mathrm{C}$ NMR spectra were recorded at 300 or 400 $\mathrm{MHz}$ and at 75 or $101 \mathrm{MHz}$ in $\mathrm{CD}_{3} \mathrm{OD}$ or DMSO- $\mathrm{d}_{6}$. Chemical shifts are given in ppm and reported to the residual solvent peak ( $\mathrm{CD}_{3} \mathrm{OD} 3.31 \mathrm{ppm}$ and $49.00 \mathrm{ppm}$; DMSO- $d_{6} 2.50 \mathrm{ppm}$ and $39.52 \mathrm{ppm}$ ). Data are reported as follows: chemical shift $(\delta)$, multiplicity $(s=$ singlet, $d=$ doublet, $t=$ triplet, $q=$ quartet, $m=$ multiplet), coupling constants, and integration. Analytical TLC were performed on silica gel $60 F_{254}$ plates. Column chromatographies were carried out on silica gel 60 (63-200 $\mu \mathrm{m})$. High- resolution mass spectra (HRMS) were measured using electrospray ionization (ESI) and Q-Tof detection. Melting points were measured with a Büchi apparatus and are reported uncorrected.

General procedure for the synthesis of monoacylated diamines. In a typical procedure, alkanediamine $(0.014$ mol) was suspended in $20 \mathrm{ml}$ DMF. Diisopropylethylamine (DIEA, $0.48 \mathrm{ml}, 2.78 \mathrm{mmol}$ ) was added, followed by the appropriate carboxylic acid (1.39 mmol), 1-Hydroxybenzotriazole (HOBt, $380 \mathrm{mg}, 2.78 \mathrm{mmol}$ ) and PyBOP $(720 \mathrm{mg}, 1.39 \mathrm{mmol})$. The reaction was allowed to proceed at room temperature 24-30 hours. DMF was then removed by evaporation under reduced pressure and the resultant residue was suspended in ethyl acetate and treated with an aqueous saturated solution of $\mathrm{NaHCO}_{3}$. Phases were separated and the aqueous one extracted with ethyl acetate. The organic layers were dried over magnesium sulfate and rotary evaporated to produce a crude yellow oil, which was purified by column chromatography (silica, $\mathrm{CH}_{2} \mathrm{Cl}_{2} / \mathrm{MeOH}$ 4:1).

For the description of compounds $\mathbf{8}, \mathbf{1 0}, \mathbf{3 0}, \mathbf{3 1}, \mathbf{3 2}, \mathbf{3 3}$, see reference 18.

tert-Butyl (S)-1-(6-aminohexylcarbamoyl)-5-(benzylami-nopentylcarbamoyl)carbamate (9) was prepared following the general procedure from $5(528 \mathrm{mg}, 1.39 \mathrm{mmol})$ yielding compound of 9 as a white solid $(372 \mathrm{mg}$, 56\%). $\mathrm{mp}<30^{\circ} \mathrm{C} .{ }^{1} \mathrm{H}$ NMR $\left(300 \mathrm{MHz}, \mathrm{CD}_{3} \mathrm{OD}\right): \delta 7.90(\mathrm{sl}, 1 \mathrm{H}), 7.35-7.26(\mathrm{~m}, 5 \mathrm{H}), 5.07(\mathrm{~s}, 2 \mathrm{H}), 3.94-3.91(\mathrm{~m}, 1 \mathrm{H})$, 3.27-3.09 (m, 2H), 2.93-289 (m, 2H), 1.71-1.29 (m, 14H), $1.44(\mathrm{~s}, 9 \mathrm{H}) .{ }^{13} \mathrm{C}$ NMR (75 MHz, CD $\left.{ }_{3} \mathrm{OD}\right): \delta 175.3$, 159.0, 157.8, 138.4, 129.5, 129.0, 128.7, 80.6, 67.3, 56.3, 41.4, 40.7, 39.9, 33.0, 30.5, 30.1, 28.7, 28.4, 27.1, 26.9, 24.1. HRMS (ESI): $\mathrm{m} / z$ calcd for $\mathrm{C}_{25} \mathrm{H}_{43} \mathrm{~N}_{4} \mathrm{O}_{5}: 479.3233[\mathrm{M}+\mathrm{H}]^{+}$; found 479.3228 .

tert-Butyl-(S)-1-(6-aminohexylcarbamoyl)-2-phenylethyl-carbamate (11) was prepared following the general procedure from 6 (369 mg, $1.39 \mathrm{mmol}$ ) yielding compound 11 as a white solid $(258 \mathrm{mg}, 51 \%) . \mathrm{mp} 60-62^{\circ} \mathrm{C} .{ }^{1 \mathrm{H}}$ NMR (400 MHz, DMSO- $\left.d_{6}\right): \delta 7.98(\mathrm{~s}, 0.25 \mathrm{H}), 7.83-7.80(\mathrm{~m}, 1 \mathrm{H}), 7.61(\mathrm{~s}$ large, $2 \mathrm{H}), 7.28-7.16(\mathrm{~m}, 5 \mathrm{H}), 6.83(\mathrm{~d}$, $0.75 \mathrm{H}, J=8.5 \mathrm{~Hz}), 4.13-4.07(\mathrm{~m}, 1 \mathrm{H}), 3.11-2.88(\mathrm{~m}, 4 \mathrm{H}), 2.76(\mathrm{t}, 2 \mathrm{H}, J=7.6 \mathrm{~Hz}), 1.54-1.46(\mathrm{~m}, 2 \mathrm{H}), 1.40-1.20(\mathrm{~m}$, $8 \mathrm{H}), 1.30(\mathrm{~s}, 9 \mathrm{H}) .{ }^{13} \mathrm{C}$ NMR $\left(75 \mathrm{MHz}\right.$, DMSO- $\left.d_{6}\right): \delta 171.4,160.9,155.2,138.1,129.2,128.0,126.2,78.0,55.8$, $38.8,38.3,37.8,28.9,28.8,28.2,27.0,26.0,25.8,25.5$. HRMS (ESI): $\mathrm{m} / \mathrm{z}$ calcd for $\mathrm{C}_{20} \mathrm{H}_{34} \mathrm{~N}_{3} \mathrm{O}_{3}: 364.2595$ $[\mathrm{M}+\mathrm{H}]^{+}$; found 364.2603 .

(R)-N-(2-Aminoethyl)-2-(2-methoxynaphthalen-6-yl)pro-panamide (12) was prepared following the general procedure from 7 (320 mg, $1.39 \mathrm{mmol}$ ) yielding compound 12 as a white solid $(117 \mathrm{mg}, 31 \%) . \mathrm{mp} 121-123^{\circ} \mathrm{C}$. ${ }^{1} \mathrm{H}$ NMR $\left(300 \mathrm{MHz}, \mathrm{CD}_{3} \mathrm{OD}\right): \delta$ 7.74-7.70 (m, 2H), $7.42(\mathrm{dd}, 1 \mathrm{H}, J 8.5,1.8 \mathrm{~Hz}), 7.20(\mathrm{~d}, 1 \mathrm{H}, J 2.4 \mathrm{~Hz}), 7.11(\mathrm{dd}, 1 \mathrm{H}$, J 9.0, $2.5 \mathrm{~Hz}), 3.89(\mathrm{~s}, 3 \mathrm{H}), 7.78(\mathrm{q}, 1 \mathrm{H}, J 7.1 \mathrm{~Hz}), 3.53-3.46(\mathrm{~m}, 1 \mathrm{H}), 3.36-3.33(\mathrm{~m}, 1 \mathrm{H}), 3.07-2.96(\mathrm{~m}, 2 \mathrm{H}), 1.53$ (d, 3H, J $7.1 \mathrm{~Hz}) .{ }^{13} \mathrm{C} \mathrm{NMR}\left(75 \mathrm{MHz}, \mathrm{CD}_{3} \mathrm{OD}\right): \delta 178.6,159.2,137.7,135.3,130.4,130.2,128.3,127.0,126.9$, 120.0, 55.7, 47.4, 40.8, 38.5, 18.8. HRMS (ESI): $\mathrm{m} / z$ calcd for $\mathrm{C}_{16} \mathrm{H}_{21} \mathrm{~N}_{2} \mathrm{O}_{2}: 273.1598[\mathrm{M}+\mathrm{H}]^{+}$; found 273.1627.

(R)-N-(6-Aminohexyl)-2-(2methoxynaphthalen-6-yl)pro-panamide (13) was prepared following the general procedure from 7 (320 mg, $1.39 \mathrm{mmol}$ ) yielding compound 13 as a white oil $(258 \mathrm{mg}, 55 \%) .{ }^{1} \mathrm{H} \mathrm{NMR} \mathrm{(300} \mathrm{MHz}$, 
$\left.\mathrm{CD}_{3} \mathrm{OD}\right): \delta 7.82(\mathrm{sl}, 1 \mathrm{H}), 7.72-7.68(\mathrm{~m}, 3 \mathrm{H}), 7.42(\mathrm{~d}, 1 \mathrm{H}, \mathrm{J} 8.6 \mathrm{~Hz}), 7.19(\mathrm{sl}, 1 \mathrm{H}), 7.11-7.08(\mathrm{~m}, 1 \mathrm{H}), 3.86(\mathrm{~s}, 3 \mathrm{H})$, $3.74(\mathrm{q}, 1 \mathrm{H}, J 7.1 \mathrm{~Hz}), 3.21-3.08(\mathrm{~m}, 2 \mathrm{H}), 1.51-1.44(\mathrm{~m}, 4 \mathrm{H}), 1.50(\mathrm{~d}, 3 \mathrm{H}, J 7.1 \mathrm{~Hz}), 1.35-1.17(\mathrm{~m}, 4 \mathrm{H}) .{ }^{13} \mathrm{C} \mathrm{NMR}$ (75 MHz, CD 3 OD): $\delta$ 177.2, 159.01, 138.1, 135.0, 130.3, 130.2, 128.1, 127.1, 126.7, 119.8, 106.6, 55.7, 47.4, 40.6, 40.1, 30.0, 28.3, 27.0, 26.7, 18.7. HRMS (ESI): $\mathrm{m} / \mathrm{z}$ calcd for $\mathrm{C}_{20} \mathrm{H}_{29} \mathrm{~N}_{2} \mathrm{O}_{2}: 329.2229$ [M+H] $^{+}$; found 329.2217.

tert-Butyl (S)-6-aminobenzylcarbamoyl-1-(1,4-diazepan-1-yl)-1-oxohexan-2-ylcarbamate (19) was prepared following the general procedure from $5(528 \mathrm{mg}, 1.39 \mathrm{mmol}$ ) yielding compound 19 as a white solid (449 $\mathrm{mg}$, 70\%). mp 88-90 ${ }^{\circ}$. ${ }^{1} \mathrm{H}$ NMR (300 MHz, $\left.\mathrm{CD}_{3} \mathrm{OD}\right): \delta$ 7.35-7.27 (m, 5H), $5.07(\mathrm{~s}, 2 \mathrm{H}), 4.41-4.33(\mathrm{~m}, 1 \mathrm{H}), 4.17-3.92$ $(\mathrm{m}, 2 \mathrm{H}), 3.73-3.33(\mathrm{~m}, 4 \mathrm{H}), 3.29-3.07(\mathrm{~m}, 4 \mathrm{H}), 2.29-1.96(\mathrm{~m}, 2 \mathrm{H}), 1.74-1.28(\mathrm{~m}, 6 \mathrm{H}), 1.44(\mathrm{~s}, 9 \mathrm{H}) .{ }^{13} \mathrm{C} \mathrm{NMR}(75$ $\left.\mathrm{MHz}, \mathrm{CD}_{3} \mathrm{OD}\right): \delta 175.2,159.0,158.4,158.3,138.5,129.5,128.9,128.7,80.8,67.3,52.4,52.3,47.8,47.2,46.7$, 45.9, 45.8, 43.7, 41.2, 32.1, 30.5, 28.7, 27.1, 26.0, 24.1, 23.8. HRMS (ESI): $\mathrm{m} / z$ calcd for $\mathrm{C}_{24} \mathrm{H}_{39} \mathrm{~N}_{4} \mathrm{O}_{5}: 463.2915$ $[\mathrm{M}+\mathrm{H}]^{+} ;$found 436.2922 .

tert-Butyl (S)-6-aminobenzylcarbamoyl-1-(piperazin-1-yl)-1-oxohexan-2-ylcarbamate (20) was prepared following the general procedure from $5(528 \mathrm{mg}, 1.39 \mathrm{mmol}$ ) yielding compound 20 as a white solid (585 mg, 94\%). $\mathrm{mp}<25^{\circ} \mathrm{C} .{ }^{1} \mathrm{H}$ NMR $\left(400 \mathrm{MHz}, \mathrm{CD}_{3} \mathrm{OD}\right): \delta$ 7.34-7.25 (m, 5H), $5.06(\mathrm{~s}, 2 \mathrm{H}), 4.47-4.44(\mathrm{~m}, 1 \mathrm{H}), 3.70-3.44(\mathrm{~m}$, $4 \mathrm{H}), 3.16-3.05(\mathrm{~m}, 2 \mathrm{H}), 2.95-2.83(\mathrm{~m}, 4 \mathrm{H}), 1.70-1.28(\mathrm{~m}, 6 \mathrm{H}), 1.42(\mathrm{~s}, 9 \mathrm{H}) .{ }^{13} \mathrm{C} \mathrm{NMR}\left(75 \mathrm{MHz}, \mathrm{CD}_{3} \mathrm{OD}\right): \delta 173.1$, 159.0, 157.9, 138.5, 129.5, 129.0, 128.7, 80.6, 67.3, 51.6, 47.0, 46.4, 46.0, 43.4, 41.3, 32.7, 30.5, $28.7,23.8$. HRMS (ESI): $m / z$ calcd for $\mathrm{C}_{23} \mathrm{H}_{37} \mathrm{~N}_{4} \mathrm{O}_{5}: 449.2764[\mathrm{M}+\mathrm{H}]^{+}$; found 449.2768 .

Benzyl (S)-1-(1,4-diazepan-1-yl)-1-oxo-3-phenylpropan-2-ylcarbamate (21) was prepared following the general procedure from 14 (416 mg, $1.39 \mathrm{mmol}$ ) yielding compound 21 as a white solid (461 mg, 87\%). $\mathrm{mp} 88$ $90^{\circ} \mathrm{C}^{\circ} \mathrm{C} .{ }^{1} \mathrm{H}$ NMR $\left(300 \mathrm{MHz}, \mathrm{CD}_{3} \mathrm{OD}\right): \delta$ 7.35-7.24 (m, 10H), 5.09-5.01 (m, 2H), 4.78-4.66 (m, 1H), 3.98-3.86 (m, $1 \mathrm{H}), 3.72-3.60(\mathrm{~m}, 1 \mathrm{H}), 3.48-3.39(\mathrm{~m}, 1 \mathrm{H}), 2.98(\mathrm{~d}, 2 \mathrm{H}, J \mathrm{H} .5 \mathrm{~Hz}), 2.92-2.83(\mathrm{~m}, 5 \mathrm{H}), 2.12-1.82(\mathrm{~m}, 2 \mathrm{H}) .{ }^{13} \mathrm{C} \mathrm{NMR}$ (75 MHz, CD $\left.{ }_{3} \mathrm{OD}\right): \delta 174.3,138.1,137.8,137.7,130.6,129.6,129.5,129.0,128.7,128.7,128.3,128.2,67.7$, 54.0, 53.8, 47.0, 45.8, 45.1, 43.4, 39.2, 39.1, 26.5, 25.7. HRMS (ESI): $\mathrm{m} / \mathrm{z}$ calcd for $\mathrm{C}_{22} \mathrm{H}_{28} \mathrm{~N}_{3} \mathrm{O}_{3}: 382.2131$ $[\mathrm{M}+\mathrm{H}]^{+}$; found 382.2130 .

tert-Butyl (S)-1-oxo-3-phenyl-1-(piperazin-1-yl)propan-2-ylcarbamate (22) was prepared following the general procedure from 6 (369 mg, $1.39 \mathrm{mmol}$ ) yielding compound 22 as a white solid (440 mg, 95\%). $\mathrm{mp} 124-$ $126{ }^{\circ} \mathrm{C} .{ }^{1} \mathrm{H}$ NMR $(300 \mathrm{MHz}$, DMSO-d 6 ): $\delta$ 7.29-7.13 (m, 5H), 4.61-4.47 (m, 1H), 3.81 (s large, 1H), $3.54-3.36(\mathrm{~m}$, $4 \mathrm{H}), 2.89-2.56(\mathrm{~m}, 6 \mathrm{H}), 1.31(\mathrm{~s}, 9 \mathrm{H}) .{ }^{13} \mathrm{C}$ NMR (75 MHz, DMSO-d 6$): \delta 169.9,155.1,137.7,129.5,128.1,126.4$, 78.1, 51.2, 44.3, 44.2, 40.8, 37.4, 28.2, 27.9. HRMS (ESI): $\mathrm{m} / z$ calcd for $\mathrm{C}_{18} \mathrm{H}_{28} \mathrm{~N}_{3} \mathrm{O}_{3}: 334.2131[\mathrm{M}+\mathrm{H}]^{+}$; found 334.2137.

(R)-1-(1,4-Diazepan-1-yl)-2-(2-methoxynaph-thalen-6-yl)propan-1-one (23) was prepared following the general procedure from $7(320 \mathrm{mg}, 1.39 \mathrm{mmol}$ ) yielding compound 23 as a white solid (343 mg, 79\%). $\mathrm{mp}>$ $230{ }^{\circ} \mathrm{C}$ (decomp.). ${ }^{1} \mathrm{H}$ NMR $\left(300 \mathrm{MHz}, \mathrm{DMSO}-d_{6}\right): \delta 7.82(\mathrm{~d}, 1 \mathrm{H}, J 8.7 \mathrm{~Hz}), 7.81(\mathrm{~d}, 1 \mathrm{H}, J 8.8 \mathrm{~Hz}), 7.74(\mathrm{~s}, 1 \mathrm{H}), 7.44$ (dd, $1 \mathrm{H}, J 8.4,1.4 \mathrm{~Hz}), 7.32$ (d, 1H, J $2.0 \mathrm{~Hz}), 7.19$ (dd, 1H, J 8.9, $2.4 \mathrm{~Hz}), 4.25-4.18(\mathrm{~m}, 1 \mathrm{H}), 3.90(\mathrm{~s}, 3 \mathrm{H}), 3.81-$ $3.34(\mathrm{~m}, 5 \mathrm{H}), 3.22-2.91(\mathrm{~m}, 3 \mathrm{H}), 2.83-2.68(\mathrm{~m}, 1 \mathrm{H}), 1.96-1.66(\mathrm{~m}, 2 \mathrm{H}), 1.41(\mathrm{~d}, 1 \mathrm{H}, J 6.7 \mathrm{~Hz}) .{ }^{13} \mathrm{C} \mathrm{NMR}(75 \mathrm{MHz}$, DMSO- $\left.d_{6}\right): \delta 172.9,172.8,157.2,137.2,137.1,133.2,133.1,129.1,128.5,127.3,127.2,126.2,126.1,125.5$, 125.4, 118.8, 105.8, 55.2, 47.1, 47.0, 45.6, 45.5, 45.4, 45.2, 44.4, 43.8, 42.1, 41.7, 41.6, 25.8, 25.7, 24.9, 20.9, 20.7. HRMS (ESI): $m / z$ calcd for $\mathrm{C}_{19} \mathrm{H}_{25} \mathrm{~N}_{2} \mathrm{O}_{2}: 313.1916[\mathrm{M}+\mathrm{H}]^{+}$; found 313.1926 .

(R)-2-(2-Methoxynaphthalen-6-yl)-1-(piperazin-1-yl)pro-pan-1-one (24) was prepared following the general procedure from $7\left(320 \mathrm{mg}, 1.39 \mathrm{mmol}\right.$ ) yielding compound 24 as a white solid (386 mg, 93\%). $\mathrm{mp}>220{ }^{\circ} \mathrm{C}$ (decomp.). ${ }^{1} \mathrm{H}$ NMR (300 MHz, DMSO-d $)$ : $\delta 7.78(\mathrm{~d}, 2 \mathrm{H}, J 8.7 \mathrm{~Hz}), 7.67(\mathrm{~s}, 1 \mathrm{H}), 7.36(\mathrm{dd}, 1 \mathrm{H}, J 8.4,1.6 \mathrm{~Hz}), 7.28$ (d, $1 \mathrm{H}, J 2.4 \mathrm{~Hz}$ ), $7.14(\mathrm{dd}, 1 \mathrm{H}, J 8.9,2.5 \mathrm{~Hz}, J \mathrm{~Hz}), 4.22$ (q, 1H, J $6.8 \mathrm{~Hz}), 3.62-3.56(\mathrm{~m}, 3 \mathrm{H}), 3.35-3.31(\mathrm{~m}, 1 \mathrm{H})$, 2.89-2.73 (m, 3H), 2.35-2.30 (m, 1H), $1.35(\mathrm{~d}, J 6.8 \mathrm{~Hz}) .{ }^{13} \mathrm{C}$ NMR (75 MHz, DMSO-d 6$): \delta$ 171.5, 157.1, 137.1, 
133.0, 129.1, 128.5, 127.3, 126.1, 125.3, 118.8, 105.8, 55.2, 43.9, 41.1, 40.2, 20.5. HRMS (ESI): $\mathrm{m} / \mathrm{z}$ calcd for $\mathrm{C}_{18} \mathrm{H}_{23} \mathrm{~N}_{2} \mathrm{O}_{2}: 299.1760[\mathrm{M}+\mathrm{H}]^{+}$; found 299.1758.

(R)-2-(2-Methoxynaphthalen-6-yl)-N-methyl-N-(2-(me-thylamino)ethyl)propanamide (25) was prepared following the general procedure from $7(320 \mathrm{mg}, 1.39 \mathrm{mmol})$, yielding compound 25 as a white oil (401 mg, 96\%). ${ }^{1} \mathrm{H}$ NMR (400 MHz, CD $\left.3 \mathrm{OD}\right): \delta 7.65$ (d, 1H, J $8.5 \mathrm{~Hz}$ ), $7.61(\mathrm{~d} 1 \mathrm{H}, J 9.0 \mathrm{~Hz}), 7.54(\mathrm{sl}, 1 \mathrm{H}), 7.25$ (dd, 1H, J 8.5, $1.7 \mathrm{~Hz}$ ), $7.11(\mathrm{~d}, 1 \mathrm{H}, J 2.3 \mathrm{~Hz}), 7.02(\mathrm{dd}, 1 \mathrm{H}, J$ 9.0, $2.5 \mathrm{~Hz}), 4.08(\mathrm{q}, 1 \mathrm{H}, J 6.8 \mathrm{~Hz}), 3.92-3.85(\mathrm{~m}, 1 \mathrm{H}), 3.80(\mathrm{~s}, 3 \mathrm{H})$, 3.14-3.01 (m, 4H), $2.89(\mathrm{~s}, 3 \mathrm{H}), 2.64(\mathrm{~s}, 3 \mathrm{H}), 1.37$ (d, 3H, J $6.8 \mathrm{~Hz}) .{ }^{13} \mathrm{C} N M R\left(75 \mathrm{MHz}, \mathrm{CD}_{3} \mathrm{OD}\right): \delta 178.2,159.2$, 137.5, 135.2, 130.5, 130.1, 128.8, 126.9, 126.8, 120.1, 106.6, 55.7, 51.7, 46.3, 44.3, 36.5, 34.1, 20.8. HRMS (ESI): $\mathrm{m} / z$ calcd for $\mathrm{C}_{18} \mathrm{H}_{25} \mathrm{~N}_{2} \mathrm{O}_{2}: 301.1911[\mathrm{M}+\mathrm{H}]^{+}$; found 301.1914 .

(3,4-Dimethoxyphenyl)(piperazin-1-yl)metha-none (26) was prepared following the general procedure from 15 (253 mg, $1.39 \mathrm{mmol}$ yielding compound 26 as a white solid (306 mg, 88\%). mp > $200{ }^{\circ} \mathrm{C}$ (decomp.). ${ }^{1} \mathrm{H} \mathrm{NMR}$ (300 MHz, CD $\left.\mathrm{CD}_{3} \mathrm{O}\right): \delta$ 7.07-7.04 (m, 3H), $3.87(\mathrm{~s}, 3 \mathrm{H}), 3.86(\mathrm{~s}, 3 \mathrm{H}), 3.79-3.66(\mathrm{~m}, 4 \mathrm{H}), 3.12-3.01(\mathrm{~m}, 4 \mathrm{H}) .{ }^{13} \mathrm{C}$ NMR (75 MHz, CD $\left.{ }_{3} \mathrm{OD}\right): \delta 172.6,152.1,150.3,128.3,121.6,112.4,112.1,56.5,56.4$ 45.4. HRMS (ESI): $\mathrm{m} / \mathrm{z} \mathrm{calcd}$ for $\mathrm{C}_{13} \mathrm{H}_{19} \mathrm{~N}_{2} \mathrm{O}_{3}: 251.1396[\mathrm{M}+\mathrm{H}]^{+}$; found 251.1398 .

(2,3-Dihydrobenzo[b][1,4]dioxin-2-yl)(pipera-zin-1-yl)-methanone (27) was prepared following the general procedure from $16(250 \mathrm{mg}, 1.39 \mathrm{mmol})$ yielding compound 27 as a white solid $(291 \mathrm{mg}, 84 \%) . \mathrm{mp} 57-59^{\circ} \mathrm{C} .{ }^{1} \mathrm{H}$ NMR (300 MHz, CD $\left.{ }_{3} \mathrm{OD}\right): \delta 6.93-6.81(\mathrm{~m}, 4 \mathrm{H}), 5.07(\mathrm{dd}, 1 \mathrm{H}, \mathrm{J} 7.1,2.6 \mathrm{~Hz}) 4.41(\mathrm{dd}, 1 \mathrm{H}, \mathrm{J} 11.8,2.6 \mathrm{~Hz}), 4.22(\mathrm{dd}$, $1 \mathrm{H}, \mathrm{J} 11.8,7.1 \mathrm{~Hz}), 3.80-3.48(\mathrm{~m}, 4 \mathrm{H}), 2.95-2.79(\mathrm{~m}, 4 \mathrm{H}) .{ }^{13} \mathrm{C} \mathrm{NMR}\left(75 \mathrm{MHz}, \mathrm{CD}_{3} \mathrm{OD}\right): \delta 167.3,144.5,144.0$, 123.0, 122.6, 118.2, 118.1, 71.4, 66.1, 47.2, 46.6, 46.0, 43.4. HRMS (ESI): $\mathrm{m} / z$ calcd for $\mathrm{C}_{13} \mathrm{H}_{17} \mathrm{~N}_{2} \mathrm{O}_{3}: 249.1239$ $[\mathrm{M}+\mathrm{H}]^{+}$; found 249.1240 .

(Piperazin-1-yl)(thiophen-2-yl)methanone (28) was prepared following the general procedure from 17 (178 $\mathrm{mg}, 1.39 \mathrm{mmol}$ yielding compound 28 as a white solid (182 mg, 67\%). mp > $230{ }^{\circ} \mathrm{C}$ (decomp.). ${ }^{1} \mathrm{H} \mathrm{NMR}$ (300 $\mathrm{MHz}, \mathrm{CD}_{3} \mathrm{OD}$ ): $\delta 7.68$ (dd, 1H, J 5.0, $1.1 \mathrm{~Hz}$ ), 7.48 (dd, 1H, J 3.7, $1.1 \mathrm{~Hz}$ ), 7.15 (dd, $\left.1 \mathrm{H}, J 5.0,3.7 \mathrm{~Hz}\right), 3.99-3.96$ (m, 4H). ${ }^{13} \mathrm{C}$ NMR $\left(75 \mathrm{MHz}, \mathrm{CD}_{3} \mathrm{OD}\right): \delta$ 165.9, 136.5, 131.2, 131.1, 128.3, 44.4. HRMS (ESI): $\mathrm{m} / \mathrm{z}$ calcd for $\mathrm{C}_{9} \mathrm{H}_{13} \mathrm{~N}_{2} \mathrm{OS}: 197.0749[\mathrm{M}+\mathrm{H}]^{+}$; found 197.0745.

4-Methyl-1-(piperazin-1-yl)pentan-1-one (29) was prepared following the general procedure from 18 (161 $\mathrm{mg}, 1.39 \mathrm{mmol}$ ) yielding compound 29 as a white solid (161 mg, 98\%). mp ${ }^{\circ} \mathrm{C} .{ }^{1} \mathrm{H} \mathrm{NMR}\left(300 \mathrm{MHz}, \mathrm{CD}{ }_{3} \mathrm{OD}\right): \delta$ 3.69-3.65 (m, 4H), 3.11-3.01 (m, 4H), 2.40-2.35 (m, 2H), 1.61-1.38 (m, 3H), $0.87(\mathrm{~d}, 6 \mathrm{H}, J 6.5 \mathrm{~Hz}) .{ }^{13} \mathrm{C} \mathrm{NMR}(75$ $\left.\mathrm{MHz}, \mathrm{CD}_{3} \mathrm{OD}\right): \delta 174.7,49.8,45.0,44.8,44.6,40.5,35.0,31.7,28.7,22.5$.

tert-Butyl (S)-1-(2-aminoethyl-(2-pyrrolidine carbamoyl)-carbamoyl)-2-phenylethylcarbamate (34). The mono-acylated diamine $10(472 \mathrm{mg}, 1.5 \mathrm{mmol})$ was dissolved in $22 \mathrm{ml}$ DMF. To the resultant solution were added DIEA ( $0.57 \mathrm{ml}, 3.4 \mathrm{mmol}$ ) followed by Z-protected proline (421 mg, $1.7 \mathrm{mmol}$ ), 1-hydroxybenzotriazole (HOBt, $456 \mathrm{mg}, 3.4 \mathrm{mmol}$ ) and PyBOP (879 $\mathrm{mg}, 1.7 \mathrm{mmol}$ ). The reaction was allowed to proceed at room temperature until judged complete by HPLC, typically 24-30 h. DMF was then removed by evaporation under reduced pressure and the resulting residue was suspended in ethyl acetate and treated with an aqueous saturated solution of $\mathrm{NaHCO}_{3}$. Phases were separated and the aqueous one extracted with ethyl acetate. The organic layers were dried over magnesium sulfate and rotary evaporated to produce a crude yellow oil, which was purified by column chromatography (silica, $\mathrm{CH}_{2} \mathrm{Cl}_{2} / \mathrm{MeOH} 10: 1$ ) leading to compound 34 as a white solid (687 mg, 83\%). mp 157-158 ${ }^{\circ} \mathrm{C} .{ }^{1} \mathrm{H}$ NMR (400 MHz, $\left.\mathrm{CDCl}_{3}\right): \delta 7.35-7.19(\mathrm{~m}, 10 \mathrm{H}), 6.64(\mathrm{~s}$ large, $1.5 \mathrm{H}), 5.38(\mathrm{~s}$ large, $0.5 \mathrm{H}), 5.21(\mathrm{~d}, 1 \mathrm{H}, J 12.4 \mathrm{~Hz}), 5.08(\mathrm{~d}, 1 \mathrm{H}, J 11.8 \mathrm{~Hz}), 4.36-4.13(\mathrm{~m}, 2 \mathrm{H}), 3.57-2.95(\mathrm{~m}, 8 \mathrm{H}), 2.17-1.82(\mathrm{~m}$, 4H), 1.37 (s, 9H). ${ }^{13} \mathrm{C}$ NMR $\left(75 \mathrm{MHz}, \mathrm{CDCl}_{3}\right): \delta 173.2,172.6,156.0,137.4,136.7,129.7,128.9,128.8,128.5$, 128.2, 127.1, 80.3, 67.7, 61.2, 56.4, 47.4, 39.5, 39.0, 38.9, 29.7, 28.6, 24.9. HRMS (ESI): $\mathrm{m} / \mathrm{z}$ calcd for $\mathrm{C}_{29} \mathrm{H}_{39} \mathrm{~N}_{4} \mathrm{O}_{6}: 539.2870[\mathrm{M}+\mathrm{H}]^{+}$; found 539.2863. 
tert-Butyl (S)-1-(2-aminoethyl-[1-benyl-(2-pyrrolidine carbamoyl)carbamoyl)-2-phenylethylcarbamate (35). A solution of $0.216 \mathrm{~g}$ of the Z-protected amine derivative $\mathbf{3 4}$ was prepared in $15 \mathrm{~mL}$ of ethanol degassed with argon and two drops of $\mathrm{AcOH}$. Under a positive argon flow, $33 \mathrm{mg}$ of $\mathrm{Pd}(\mathrm{OH})_{2}$ catalyst was slowly added to the vigorously stirring degassed solution. After $4 \mathrm{~h}$, the suspensionwas filtered through Celite. The Celite pad was washed with more ethanol and the filtrate was concentrated under vacuum. The resultant white solid was recristallized in DCM/ether. Compound $35(0.131 \mathrm{~g}, 81 \%)$ was obtained as a white solid. mp $57-58^{\circ} \mathrm{C} .{ }^{1} \mathrm{H} N M R$ $\left(400 \mathrm{MHz}, \mathrm{DMSO}-d_{6}\right): \delta$ 7.30-7.19 $(\mathrm{m}, 5 \mathrm{H}), 4.25-4.21(\mathrm{~m}, 1 \mathrm{H}), 3.71-3.7(\mathrm{~m}, 1 \mathrm{H}), 3.27-3.21(\mathrm{~m}, 4 \mathrm{H}), 3.10-2.94(\mathrm{~m}$, 3H), 2.84-2.79 (m, 1H). ${ }^{13} \mathrm{C}$ NMR (75 MHz, DMSO-d $\left.)\right): \delta 176.4,174.7,138.7,130.5,129.4,127.7,80.7,61.6$, $57.7,47.9,40.0,39.9,39.4,31.8,28.7,26.7$. HRMS (ESI): $\mathrm{m} / z$ calcd for $\mathrm{C}_{21} \mathrm{H}_{33} \mathrm{~N}_{4} \mathrm{O}_{4}: 405.2502[\mathrm{M}+\mathrm{H}]^{+}$; found 405.2509 .

\section{Acknowledgements}

Thanks are expressed to Mr. Pierre Sánchez for his help in the obtaining mass spectrometry spectra.

\section{Supplementary Material}

Copies of ${ }^{1} \mathrm{H}$ and ${ }^{13} \mathrm{C}$ NMR spectra of the new compounds 9, 11-13, 19-29, and $34-35$ can be found in the supplementary material file.

\section{References}

1. Chen, Y.; Loredo, A.; Gordon, A.; Tang, J.; Yu, C.; Ordonez, J.; Xiao, H. Chem Commun. 2018, $54,7187$. https://doi.org/10.1039/c8cc03819h

2. Yuan, L.; Lin, W.; Xie, Y.; Chen, B.; Zhu, S. J. Am. Chem. Soc. 2012, 134, 1305-1315. https://doi.org/10.1021/ja2100577

3. Yoshihara, T.; Yamaguchi, Y.; Hosaka, M.; Takeuchi, T.; Tobita, S. Angew. Chem. Int. Ed. 2012, 51, 41484151.

https://doi.org/10.1002/anie.201107557

4. Tamura, T.; Tsukiji, S.; Hamachi, I. J. Am. Chem. Soc. 2012, 134, 2216-2226. https://doi.org/10.1021/ja209641t

5. Shi, H.; Cheng, X.; Sze, S. K.; Yao, S. Q. Chem. Commun. 2011, 47, 11306-11308. https://doi.org/10.1039/C1CC14824A

6. Shi, H.; Uttamchandani, M., Yao, S. Q. Chem. Asian J. 2011, 6, 2803-2815. https://doi.org/10.1002/asia.201100523

7. Kierat, R. M.; Thaler, B. M. B.; Krämer, R. Bioorganic \& Medicinal Chemistry Letters 2010, 20, 1457-1459. https://doi.org/10.1016/i.bmcl.2009.03.171

8. Kalesh, K. A.; Tan, L. P.; Lu, K.; Gao, L.; Wang, J.; Yao, S. Q. Chem. Commun. 2010, 46, 589-591. https://doi.org/10.1039/b919744c 
9. Liu, K.; Shi, H.; Huogen, X.; Chong, A. G. L.; Bi, X.; Chang, Y.-T.; Tan, K. S. W.; Yada, R. Y.; Yao, S. Q. Angew. Chem. Int. Ed. 2009, 48, 8293-8297.

https://doi.org/10.1002/anie.200903747

10. Gao, C.-Z.; Dong, W.; Cui, Z.-W.; Yuan, Q.; Hu, X.-M.; Wu, Q.-M.; Han X.; Xu, Y.; Min Z.-L. J. Enzyme Inhib. Med. Chem. 2019, 34, 150-162.

https://doi.org/10.1080/14756366.2018.1530224

11. Liu, H. ; Tian, Y. ; Lee, K. ; Krishnan, PR ; Wang, M. K.-M. ; Whenlan, S. ; Mevers, E. ; Soloveva, V. ; Dedic, B. ; Liu, X. ; Cunningham, J. M. J. Med. Chem. 2018, 61, 6293-6307.

https://doi.org/10.1021/acs.jmedchem.8b00704

12. Mallikarjuna, S. M. ; Sandeep, C. ; Padmashali, B. IJPSR 2017, 8, 2879-2885. https://doi.org/10.13040/IJPSR.0975-8232.8(7).2879-85

13. Yeung, K.-S.; Qiu, Z.; Yin, Z.; Trehan, A.; Fang, H.; Pearce, B.; Yang, Z.; Zadjura, L.; D’Arienzo, C. J.; Riccardi, K.; Shi, P.-Y.; Spicer, T. P.; Gong, Y. F.; Browning, M. R.; Hansel, S.; Santone, K.; Barker, J.; Coulter, T.; Lin, P.-F.; Meanwell, N. A.; Kadow, J. F. Bioorganic \& Medicinal Chemistry Letters 2013, 23, $203-208$. https://doi.org/10.1016/i.bmcl.2012.10.117

14. Kamal, A.; Tamboli, J. R.; Ramaiah, M. J.; Adil, S. F.; Rao, G. K.; Viswanath, A.; Mallareddy, A.; Pushpavalli, S. N. C. V. L., Pal-Bhadra, M. Chem. Med. Chem. 2012, 7, 1453-1464.

https://doi.org/10.1002/cmdc.201200205

15. Kamal, A.; Reddy, M. K.; Ramaiah, M. J.; Srikanth, Y. V. V.; Ranjender; Reddy, V. S.; Kumar, G. B.; Pushpavalli, S. N. C. V. L.; Bag, I.; Juvekar, A.; Sen, S.; Zingde, S. M.; Pal-Bhadra, M. Chem. Med. Chem. 2011, 6, 1665-1679.

https://doi.org/10.1002/cmdc.201100207

16. Kamal, A.; Balakishan, G.; Ramakrishna, G.; Shaik, T. B.; Sreekanth, K.; Balakrishna, M.; Rajender; Dastagiri, D.; Kalivendi, S. V. Eur. J. Med. Chem. 2010, 45, 3870-3884.

https://doi.org/10.1016/i.ejmech.2010.05.041

17. Fattori, D.; Rossi, C.; Fincham, C. I.; Caciagli, V.; Catrambone, F.; D'Andrea, P.; Felicetti, P.; Gensini, M.; Marastoni, E. ; Nannicini, R. ; Paris, M.; Terracciano, R. ; Bressan, A. ; Giuliani, S. ; Maggi, C. A.; Meini, S.; Valenti, C.; Quartara, L. J. Med. Chem. 2007, 50, 550-565.

https://doi.org/10.1021/jm.061143k

18. Sharma, S.; Thorat, S. H.; Gonnade, R. G.; Jasinski, J. P.; Butcher, R.; Haridas, V. Eur. J. Org. Chem. 2017, 1120-1124.

https://doi.org/10.1002/ejoc.201601365

19. Feldman, A. M. Cardiovasc. Drug Rev. 1993, 11, 1-11. https://doi.org/10.1111/j.1527-3466.1993.tb00264.x

20. Manoury, P. M.; Binet, J. L.; Dumas, A. P.; Lefevre-Borg, F.; Cavero, I. J. Med. Chem. 1986, $29,19-25$. https://doi.org/10.1021/jm00151a003

21. Bender, J. A.; Meanwell, N. A.; Wang, T. Tetrahedron 2002, 58, 3111-3128. https://doi.org/10.1016/S0040-4020(02)00165-5

22. Jacobson, A. R.; Makris, A. N.; Sayre, L. M. J. Org. Chem. 1987, 52, $2592-2594$. https://doi.org/10.1021/jo00388a048

23. Hall, H. K. J. Am. Chem. Soc. 1956, 78, 2570-2572.

https://doi.org/10.1021/ja01592a066

24. Hill, A. J.; Aspinall, S. R. J. Am. Chem. Soc. 1939, 61, 822-825.

https://doi.org/10.1021/ja01267a504 
25. Chou,W.-C.; Tan, C.-W.; Chen, S.-F.; Ku, H. J. Org. Chem. 1998, 63, 10015-10017. https://doi.org/10.1021/jo980830j

26. Wang, T.; Zhang, Z. X.; Meanwell, N. A. J. Org. Chem. 1999, 64, 7661-7662. https://doi.org/10.1021/jo9908501

27. Zhang, Z. X.; Yin, Z. W.; Meanwell, N. A.; Kadow, J. F.; Wang, T. Org Lett. 2003, 3399-3402. https://doi.org/10.1021/ol0300773

28. Pringle, W. Tetrahedron Letters 2008, 49, 5047-5049. https://doi.org/10.1016/j.tetlet.2008.06.044

29. Lai, L.-L.; Wang, E.; Luh, B.-J. Synthesis 2001, 361-363. https://doi.org/10.1055/s-2001-11425

30. Pappas, K.; Zhang, X.; Tang, W.; Fang, S. Tetrahedron Letters 2009, 50, 5741-5743. https://doi.org/10.1016/j.tetlet.2009.07.142

31. Bandgar, B. P.; Pandit, S. S. Tetrahedron Lett. 2003, 44, 3855-3858. https://doi.org/10.1016/S0040-4039(03)00684-1

32. Coste, J.; Le-Nguyen, D.; Castro, B. Tetrahedron Letters 1990, 31, 205-208. https://doi.org/10.1016/S0040-4039(00)94371-5

33. Hoeg-Jensen, T.; Jakobsen, M. H.; Holm, A. Tetrahedron Letters 1991, 32, 6387-6390. https://doi.org/10.1016/0040-4039(91)80176-7

34. Frérot, E.; Coste, J.; Pantaloni, A.; Dufour, M.-N.; Jouin, P. Tetrahedron 1991, 47, 259-270. https://doi.org/10.1016/S0040-4020(01)80922-4

35. Mendes de Silva, J. F.; Walters, M.; Al-Damluji, S.; Ganellin, R. Bioorg. \& Med. Chem., 2008, 16, 72547263.

https://doi.org/10.1016/i.bmc.2008.06.037

36. Salom-Roig, X. J.; Fawaz, G.; Martinez, J.; Burguete, M. I.; Galindo, F.; Luis, S. V.; Miranda, M. A.; MorantMiñana, M. C.; Pérez-Prieto, J. Tetrahedron Letters 2009, 50, 4859-4862.

https://doi.org/doi:10.1016/j.tetlet.2009.06.047

37. Burguete, M. I.; Fawaz, G.; Galindo, F., Izquierdo, M. A.; Luis, S. V.; Martinez, J.; Salom-Roig, X. J. Tetrahedron 2009, 65, 7801-7808.

https://doi.org/doi:10.1016/j.tet.2009.07.031

38. Kon, K.; Kohari, Y.; Murata, M. Tetrahedron Letters 2019, 60, 415-418. https://doi.org/10.1016/j.tetlet.2018.12.049

39. Gorde, A. B.; Ramapanicker, R. J. Org. Chem. 2019, 84, 1523-1533. https://doi.org/10.1021/acs.joc.8b02945

40. Mahato, C. K. ; Mukherjee, S. ; Kundu, M. ; Pramanik, A. J. Org. Chem. 2019, 84, 1053-1063. https://doi.org/10.1021/acs.joc.8b02393

41. Ruíz- Pérez, K. M. ; Quiroz-García, B. ; Hernández-Rodríguez, M. Eur. J. Org. Chem. 2018, 83, 5763-5772. https://doi.org/10.1002/ejoc.201800886

42. List, B.; Lerner, R. A.; Barbas, C. F., III. J. Am. Chem. Soc. 2000, 122, 2395-2396. http://dx.doi.org/10.1021/ja994280y

43. Krattiger, P.; Kovasy, R.; Revell, J. D.; Ivan, S.; Wennemers, H. Org. Lett. 2005, 7, 1101. http://doi.org/10.1021/ol0500259 